\title{
Institutionalizing service-learning as a social work pedagogy: experiences, challenges and contributions to acquisition of competencies
}

\author{
Melody Ambangan
}

Southern Christian College, Philippines

\begin{abstract}
Social Work Education (SWE) in the Philippines is a competency-based academic discipline that focuses on the development of student practice behaviors. The goal of SWE is to demonstrate the integration and application of the competencies in practice with various client systems. This is where the SWE of Southern Christian College (SCC) saw the need to adopt service-learning (SL) as a pedagogy that would aid, assess, and enhance students' readiness for professional practice. Since it is a combination of academic instruction and community service to address identified community needs, SL is viewed to be an effective vehicle to ensure that students apply what they learn from their classes to address real-world problems in communities. This paper will present the process of how SL had been introduced as an academic framework in one of the social work courses in SCC in 2010 and will particularly highlight the experiences, challenges, gains and learning insights. Experiences of students and faculty revolved around their engagements, challenges encountered, personal and professional learning, and social and psychological gains. Based on the data gathered, an SL framework was developed to reflect the practice of $\mathrm{SL}$ in the SCC-SWE. In conclusion, SL as a pedagogy in social work education has contributed to the acquisition and development of basic competencies in terms of knowledge, values and attitudes and skills. The gains which service-learners identified superseded the challenges which they encountered along the various phases.
\end{abstract}

\section{Keywords}

Education, framework, service-learners, community.

Fecha de recepción: 24/XI/2021

Fecha de aceptación: 9/XII/2021

Ambangan, M. (2021). Institutionalizing service-learning as a social work pedagogy: experiences, challenges and contributions to acquisition of competencies. RIDAS, Revista Iberoamericana de Aprendizaje Servicio, 12, 35-44. DOI10.1344/RIDAS2021.12.5 


\section{Institucionalizar el aprendizaje-servicio como pedagogía del trabajo social: experiencias, desafíos y contribuciones a la adquisición de competencias}

\section{Resumen}

La Educación en Trabajo Social en Filipinas es una disciplina académica basada en competencias que se enfoca en el desarrollo de conductas prácticas de los estudiantes. Su objetivo es demostrar la integración y aplicación de las competencias en la práctica con varios sistemas de clientes. Aquí es donde el Southern Christian College (SCC) vio la necesidad de adoptar el aprendizaje-servicio (ApS) como una pedagogía que ayudaría, evaluaría y mejoraría la preparación de los estudiantes para la práctica profesional. Dado que es una combinación de instrucción académica y servicio comunitario para abordar las necesidades comunitarias identificadas, el ApS se considera un vehículo eficaz para garantizar que los estudiantes apliquen lo que aprenden en sus clases para abordar problemas del mundo real en las comunidades. Este artículo presenta el proceso de cómo el ApS se introdujo como un marco académico en uno de los cursos de Trabajo Social en el SCC en 2010 y destaca particularmente las experiencias, desafíos, logros y resultados de aprendizaje. Las experiencias de los estudiantes y profesores giraron en torno a sus compromisos, desafíos encontrados, aprendizaje personal y profesional y las mejoras sociales y psicológicas. Sobre la base de los datos recopilados, se desarrolló un marco de ApS para reflejar la práctica del ApS en el SCC. En conclusión, el ApS como pedagogía en la Educación en Trabajo Social ha contribuido a la adquisición y desarrollo de competencias básicas en términos de conocimientos, valores y actitudes y habilidades. Los beneficios que identificaron los estuidiantes superaron los desafíos que encontraron a lo largo de las diversas fases.

\section{Palabras clave}

Educación, marco, estudiante, comunidad. 


\section{Institucionalització de l'aprenentatge servei com a pedagogia del treball social: experiències, reptes i contribucions a l'adquisició de competències}

\section{Resum}

L'Educació del Treball Social a les Filipines és una disciplina acadèmica basada en competències que se centra en el desenvolupament de conductes pràctiques dels estudiants. El seu objectiu és demostrar la integració i aplicació de les competències a la pràctica amb diversos sistemes de client. Aquí és on el Southern Christian College (SCC) va veure la necessitat d'adoptar l'aprenentatge servei (ApS) com una pedagogia que ajudés, avalués i millorés la preparació dels estudiants per a la pràctica professional. Com que es tracta d'una combinació d'instrucció acadèmica i servei comunitari per atendre les necessitats identificades de la comunitat, l'ApS es considera un vehicle eficaç per garantir que els estudiants apliquin el que aprenen de les seves classes per abordar problemes del món real a les comunitats. Aquest article presenta el procés com s'ha introduït l'ApS com a marc acadèmic en un dels cursos de Treball Social a SCC I'any 2010 i destaca especialment les experiències, els reptes, els guanys i els aprenentatges. Les experiències dels estudiants i del professorat van girar al voltant dels seus compromisos, els reptes trobats, l'aprenentatge personal i professional i els guanys socials i psicològics. A partir de les dades recollides, es va desenvolupar un marc d'ApS per reflectir la seva pràctica al SCC. En conclusió, I'ApS com a pedagogia de l'Educació en Treball Social ha contribuït a l'adquisició i desenvolupament de les competències bàsiques en termes de coneixements, valors i actituds i habilitats. Els guanys que van identificar els estudiants van substituir els reptes que van trobar al llarg de les diferents fases.

\section{Paraules clau}

Educació, marc, estudiant, comunitat. 


\section{Introduction}

Social work is not only an academic discipline but also practice-based profession. This is emphasized in its global definition crafted by the International Federation of Social Workers (2014). It focuses on the development of student practice behaviors. In the Philippine Commission for Higher Education (CHED) Memorandum Order 11 s. 2010 (CHED, 2010), the Bachelor of Science in Social Work (BSSW) shall adhere to the global standard of social work education such as knowledge and skills to address and transform social inequalities, shall be able to network and mobilize resources and able to apply the social work values and ethical principles. In terms of goal, the degree program shall manifest integration and application of the competencies in practice with the target client system the individuals, families, groups and communities.

The aforementioned ideals for social workers based on observations in actual practice, however, are far from these standards. Some lack the skills to carry out comprehensive assessments (Lumos Protecting Children, Providing Solution, 2012) and there are many who are not skilled enough to recognize the real need.

Apart from what have been cited, social workers should also be skillful in analytical, communication, organizational and interpersonal skills, professional demeanor and time management skills. To address the need for prepare social workers and equip them with basic competencies, the Social Work program of Southern Christian College utilizes servicelearning as a pedagogy to assess and enhance students' competencies with the aim of preparing them for professional practice.

Service-learning is combination of classroom instruction with community service to address community needs. What students learn inside the classroom, they bring and apply to realworld problems in their respective communities or their communities of placement. It is common knowledge among service-learning advocates and implementers that the goal of servicelearning is to enhance and enrich the learning of students in the course materials, influence student attitudes and self-awareness, specifically for social work students, these take place while working collaboratively with diverse community groups and help the students to develop social work skills.

Service-learning has been a pedagogy in the Social Work Program of Southern Christian College for several years already since the program's offering in 2006. Students involved in servicelearning have their respective roles and responsibilities in every undertaking.

The lengthy process of service-learning engagement begins with investigation where students explore the community and identify the needs, planning where they analyze the problem and make decision on it, to the action they take related to the problem. The way service-learning addresses the problem may either be by direct or indirect 
service, research or advocacy, both are also essential skills for a social worker in the field.

Looking at service-learning as an adopted pedagogy in the BS in Social Work Program of Southern Christian College, this paper will present the process of how service learning has been institutionalized in social work courses in the institution. Particularly, this aimed to describe the experiences of students during their service-learning engagements, determine contributions of service-learning to the acquisition of basic social work competencies, and present the service-learning framework developed that reflects the practice of the SCC Social Work program.

\section{Methodology}

Utilizing the mixed-method in research and adopting the descriptive-narrative design, this paper features both quantitative and qualitative data from faculty members engaged in servicelearning, and from 34 students and graduates of the BS in Social Work Program of Southern Christian College. A survey questionnaire was used for the 34 respondents and two focus groups with six members each set were engaged for a discussion using a semistructured interview guide.

All respondents and participants involved in the data gathering provided their consent to voluntarily participate. In the analysis of quantitative data particularly on the contribution of service-learning to the acquisition of competencies, descriptive statistics were used such as frequency counts, percentages and means. Means of answers to the contributions of servicelearning were given the following interpretations: $1.0-2.0$ - not contributory; 2.01-3.0 - moderately contributory; and 3.01-4.0 - highly contributory. Experiences and challenges in service-learning engagements were presented as narratives.

\section{Results and discussion}

Service-learning in Social Work Education in Southern Christian College has been integrated in three major courses which are part of the program's core curriculum. These courses are Social Work Program Development and Management, Social Work Education and Training and Social Welfare Policies, Programs and Services. Through an interview with faculty members engaged in service-learning, and with the results of the focus group discussions with service-learners, the process of service-learning engagement was classified in stages as follows:

1. classroom orientation;

2. grouping and group dynamics;

3. community protocol;

4. actual engagement and formative evaluation;

5. culmination and celebration; and

6. post-engagement and submission of requirements (see Figure 1 ). 
Figure 1. Count of service-learning projects

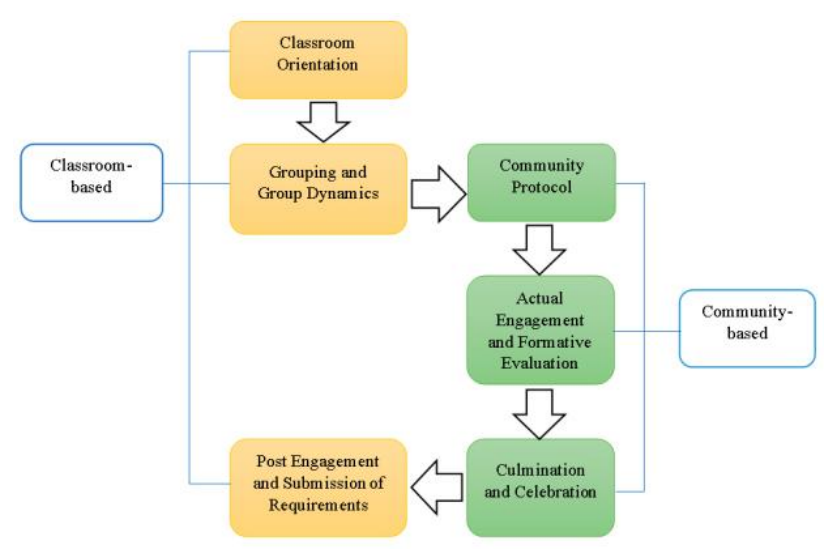

Source: own elaboration

During the classroom orientation, students are oriented about servicelearning and its significance in their process of learning. Students are also prepared for actual engagement by developing basic skills and critical understanding of community problems and concerns. Students are also reminded of ethics to be observed, role and responsibility-taking, systems to be utilized and possible activities to engage in. In the grouping and group dynamics, students are facilitated to develop teamwork among themselves.

They also do pre-engagement activities per group like community visits, community needs appraisal, and resource identification. They also brainstorm as a group how they can apply their learned knowledge and skills to address identified community needs and concerns. While doing community visits, community protocols are also being done simultaneously such as courtesy visit and seeking of approval from the barangay local government council, initial meeting with the target community sector, and presentation of proposed projects to solicit possible support from different stakeholders. In the actual engagement, students plan the implementation with the community sector identified. After the full process, students are evaluated by the community through both quantitative and qualitative means, by the course instructor and by their team members. Debriefing is an important aspect of this stage to process students' learning. Strengths, weaknesses and opportunities for improvement were identified to give way to the development of newly discovered skills. Culmination of the engagement follows with a celebration highlighting the output and outcome of the partnership and engagement. The last stage which is the post-engagement is a time for students to work either individually or as a group to produce evidence of their learning from the service rendered by working on the course requirements such as photo and process documentation, reflections, video and presentations among others. Sharing of learning is facilitated by the course instructor.

While engaging in service-learning, students encountered challenges and issues which include financial constraints, soliciting participants' support and cooperation, participants' availability to join in set activities, time constraint, differing attitude and personal values. Expenses are bigger when students go to communities for service-learning rather than just stay inside the classroom. They need to prepare additional funds for mobility and transportation, needs for additional logistics, snacks and meals for 
community participants, and actual project implementation. Usually, communities for service-learning are rural communities in the outskirts of the municipality. Children and young people are not as participative and cooperative as children more progressive areas. Women are used to staying at home rather than participating in community activities. With this, service-learners shared that they needed to take more time and effort to gain the trust and willingness of the people in the community. There were also other instances that activities have to be cancelled or postponed because of participants' non-availability. This leads to time constraint where service-learners have to extend their time beyond what is stipulated in the original plan or proposal. Moreover, challenges also came out because of differing personal values and priorities. Misunderstanding sometimes surface within the group but service-learners said that they learned how to listen to each side and come up with decisions which are agreed upon by all members of the group.

Despite the challenges encountered by students, their overall experience revealed that the pedagogy has contributed to their acquisition of competencies, specifically acquisition of practical knowledge, values and skills. In the knowledge acquisition, 98.17 percent of the respondents agreed that service-learning is highly contributory $(\mu-3.46)$ to the enhancement of their knowledge in the generalist helping process. Furthermore, service-learning provides critical understanding of the planned change process and deeper understanding of ethical considerations and protocols in community work, provides critical understanding of how social realities impact human functioning and better knowledge of government programs, policies and services, enhances and broadens their understanding of career and occupational options as well as their horizons and choices and teaches them civic responsibility.

Sharing of participants in the focus group discussions supported this result. One said, "Because of service-learning, I become more responsible in my work because I already know how to manage and run the program. I already know how to utilize resources and the dos and don'ts of running a program because I already went through it." Another said, "Service-learning enabled me to say that when I am already a professional, I want to work with children. Service-learning let me think and see many career options, which, in turn, let me foresee a career path to head to".

In terms of contributions to acquisition of appropriate attitude and values, quantitative results revealed that 98.87 percent of the student respondents agreed that service-learning was highly contributory $(\mu=3.55)$ in this aspect. Particularly service-learning's contributions are on providing venue for critical self-reflection, facilitation of selfdiscovery, bettering perception of one's self-worth, self-confidence and selfesteem. Moreover, it helped servicelearners grow commitment to human service and social responsibility, develop empathy, foster respect to diversity and understand cultural, 
ethnic and social similarities and differences, develop individual sense of citizenship and nationalism and appreciate social work values, principles and ethics.

In the acquisition of skills, 99.62 percent of the 34 respondents agreed that service-learning is highly contributory $(\mu=3.53)$. It aids students in the acquisition of specific skills such as using supervision, networking and partnership-building, working with multidisciplinary, interdisciplinary or transdisciplinary teams, mobilizing and utilizing resources, and concretizing the profession's practice of intervention in different contexts. Added to these, service-learning also contributed to the students' acquisition of skills in leadership, interpersonal relations, communication, problem-solving and responding to social realities that affect communities.

These statements from the participants of the focus group discussions support the aforementioned results on the contribution of service-learning to the acquisition of values. An insight from a participant stated how his/her engagement with service-learning helped him/her boost her confidence, saying, "I was not really confident in facing people, especially those who are in high positions or status. But since our service-learning engagement required us to do so, I was able to overcome my shyness and conquered my fears". S/he added that through service-learning, s/he discovered more about herself and was able to do things $\mathrm{s} /$ he thought $\mathrm{s} /$ he could not do. This is similar to what another participant shared and said, "My self-confidence and self-esteem increased because of what I have been through during our service-learning". Another one recalled how s/he dealt with instances where there were some 'hardheaded' individuals in the group by saying, "In instances like this, I can always recall what is stated in the Social Work Code of Ethics that whatever kind of people you are dealing with, they are individuals with inherent worth and dignity". Similarly, respect for others is fostered in service-learning. This is concretized by a participant's statement which said, "You will further develop your respect towards others especially that you are working with people from different religious background and social or ethnic groups. The principles of social work indeed came in handy during this time". Empathy was manifested in the sharing where it is developed by students as they engage in service-learning, and that by establishing empathy, students are capable of engaging in further character development.

In the aspect of social work-related skills acquisition and development, service-learning has contributed highly $(\mu=3.53)$ as revealed in the 99.61 percent of respondents who agreed. In particular, skills which were enhanced include self-expression, ability to use supervision, networking and partnership-building, work with multidisciplinary, interdisciplinary or transdisciplinary teams, and mobilization and utilization of resources. Moreover, other skills which were discovered and enhanced covered ability to work in various contexts, leadership, interpersonal relation, 
communication, problem-solving and identifying and responding to the effects of social realities to communities. The quantitative results are supported by qualitative data which came out from the sharing of participants during the focus group discussions. One participant believes that "We are now capable of working in various settings. During our servicelearning engagement, we were taught to work in different settings and contexts".

Participants gave their individual reflections on their experiences with service-learning. Such reflections revolved around their learnings and how they affect their personal and professional life. During the FGDs, all the participants shared and expressed their learning and realizations during their engagements. They shared that service-learning helped them a lot in so many ways serving as their foundation for whatever they are doing either in actual professional practice or in field instruction. They also reflected that service-learning really made them explore and discover themselves including the discovery of untapped potentials.

Service-learning also helped them develop their competencies in terms of knowledge, values and attitudes and skills. They were able to perform multiple tasks and roles, discover techniques and strategies which were once unknown to them and could not have been discovered if they only stayed within the four walls of the classroom.

For the FGD participants, learning does not just happen inside the campus or the classroom but could be best gained from the experiences with and of people in communities. The fulfillment they felt was at a different level because they went through a real-life scenario and actual learning where they experienced reality and applied the things that they had learned inside the classroom.

\section{Conclusions}

In conclusion, the mean results of the quantitative data and the consistency of the qualitative data lead to the conclusion that service-learning as a pedagogy utilized in the Southern Christian College Social Work Program has contributed to the acquisition and development of competencies knowledge, values, and skills - of the students. The gains which servicelearners identified superseded the challenges which they have encountered which proved that their service-learning experiences have been meaningful and contributory to their personal life and to their professional integrated social work practice.

\section{Acknowledgements}

This paper has been written completely through the invaluable data gathered by Ms. Leah Mae Cabangbang in her undergraduate thesis. Moreover, the unselfish sharing of the BSSW alumni who had their service-learning engagements on the year 2013-2014 and 2014-2015 contributed much to this paper as well. Personal acknowledgment also goes to Dr. Ma. Elena B. Bugacia, former Vice-President for Academic Affairs of Southern 
Christian College and Dr.

EmervenciaLigutom, former Service-

Learning Director of Silliman University, who both paved way for the

writer/authorof this paper to get a grasp of what service-learning is. To PEPP, my son, whose existence becomes the writer's motivation to make this world a better place to live in by making small steps of positive changes through service-learning.

\section{References}

Commission for Higher Education [CHED]. (2010). Policies and standards for bachelor of science in social work program. Memorandum Order No. 11, series. 10. https://ched.gov.ph/wpcontent/uploads/2017/10/CMO-No.11s2010.pdf

International Federation of Social Workers. (2014). Global definition of social work.

https://www.ifsw.org/what-is-socialwork/global-definition-of-social-work/

Lumos Protecting Children, Providing Solutions (2012). Challenges in developing social services. http://www.wearelumos.org/stories/cha llenges-developing-social-services 